This is the Accepted Version of Ramgotra, Manjeet (2014) 'Conservative Roots of Republicanism.' Theori a: A Journal of Social and Political Theory, 61 (139). pp. 22-49. Published by Berghahn and available at: 1 $0.3167 /$ th. 2014.6113902

Accepted Version downloaded from SOAS Research Online: http://eprints.soas.ac.uk/18928/

\title{
Conservative Roots of Republicanism
}

Manjeet Ramgotra - SOAS, University of London

Abstract: Republicanism is generally said to promote virtue and equal political participation, yet many historical republics and republican theories endorse the hierarchical political participation of the upper and lower social classes and recommend a centralised executive power. Republican constitutions incorporate the authority of the nobles, the freedom of the people and the political power of one man. Cicero formulates this understanding of the republic, which endures in the ideas of Machiavelli and Montesquieu. I characterise this school of thought as conservative because it promotes the preservation of the social hierarchy, private property and stability; moreover, it harnesses change by advancing a policy of expansion. I challenge the mainstream Cambridge School interpretation by tracing the trajectory of conservative republican ideas in the thought of Cicero, Machiavelli and Montesquieu. Few interpretations relate the republicanism of these three thinkers to each other; hence this reading contributes a new way of thinking about republicanism.

Keywords: Cicero, conservative, empire, hierarchy, Machiavelli, Montesquieu, republicanism 
As Republican Rome fell, Cicero defended republican institutions against threats of populism and absolutism. He promoted a mixed constitution that combined the political authority of the patricians and the freedom of the people. This republican constitution integrated the leadership of two consuls (Cicero 1999a: I-65-69). The organisation of patrician and popular institutions (senate and tribunes) was hierarchical. ${ }^{1}$ Although the power of the two consuls was restricted, this centralised leadership facilitated both Rome's rise to greatness and downfall. According to Cicero, Rome's republican constitution created stability and harmony amongst the social orders. His experience and knowledge of this great republic have had a lasting influence.

More than a millennium later, Machiavelli developed this understanding of republicanism in his analysis of Livy's Roman history. Machiavelli presented Rome as a perfect republic. He claimed that social conflict made Rome free and great (Machiavelli 1983: I-5). Machiavelli applauded Rome's retention of the office of king. He contended that a centralised princely power could mediate the opposing interests of the nobles and the people and redirect this energy to the common pursuit of expansion (Althusser 1999: 49-52; Hörnqvist 2005; Springborg 1992: 181-5, 210-48).

Two centuries after the discoveries of the Americas and the navigational route around the southern tip of Africa, Montesquieu transformed Enlightenment understandings of the republican constitution through his highly influential theory of the separation and balance of powers. He put forward the argument that when power is divided into its executive and legislative functions, individuals are free from arbitrary power. Although Montesquieu's constitution is premised on the mechanics of power, he integrated the social classes in a bicameral legislature and established the executive power of one man. He also argued for an independent judiciary and contended that commerce brings peace (Montesquieu 1989: XI-6, XX-1-2). Nevertheless, his 
enthusiasm for international trade in a competitive market promoted colonialism and the structure of his fundamental constitution facilitated the pursuit of colonial empire (Montesquieu 1989: XXI-21).

Cicero, Machiavelli and Montesquieu developed a conception of republicanism in which the political constitution integrates the two main social classes hierarchically and establishes a strong leadership. This leadership protects internal freedom and security and defends the republic against external aggression. All three thinkers advocate an expansive republic.

I characterise this particular understanding of republicanism as conservative because it preserves the social hierarchy, protects private property, maintains stability and promotes the principle of equity, which substantiates an inegalitarian conception of both justice and virtue. The hierarchical structure endorses the predominance of the (often hereditary) nobility as an authoritative political body and substantially limits the participation of the people. The republic is a mixed constitution that incorporates political power of one, with the political authority of the few and the political liberty of the many. On my reading of three republican thinkers, this specific constitution contains all three elements, notably the democratic, and extends from the Roman Republic.

In my view, republic is not incompatible with monarchy. Both are legitimate and frequently mixed types of government because both posit the rule according to laws and locating political power and authority in different sites - such that power is not consolidated within a single site or body as that of one man or the many. In instituting political power and authority in different sites the role of the landed social classes is crucial. They bridle the power of the monarch and their landed interests maintain social stratification such that political equality is not instituted. Opposites of the republic are the despotic (absolute and tyrannical) government of one man alone and the 
licentious rule of the many. Neither of these types rule according to laws established in the general interest; rather they rule according to particular whims or desires. David Wootton reiterates this idea in his observation that the republic came to refer to 'a mixed form of government, where monarchy was prevented from degenerating into a tyranny, where popular power was prevented from degenerating into mob rule' (Wootton 1994: 6; see also Urbinati 2012).

In my reading of republicanism as conservative, the landed nobility exercise political authority, the people enjoy liberty and one man wields imperium - the power to rule according to accepted legislation (Richardson 1991: 4-6, 8-9). Reinforcing this structure is the idea that the popular social class is not apt to rule, but should have some political participation since it poses a threat to the republic. Rights and duties are distributed according to rank. The nobility enjoy the positive political right and freedom to formulate and deliberate upon public policy and the people acquire the positive political right to elect leaders and the negative freedom to live in security. In theory, the people could oppose legislative proposals through the veto granted to either popular leaders or representatives but, in practice, it was made difficult for them to do so. At the same time, this is a very strong constitution that both confronts change and corruption without degenerating into either tyranny or anarchy.

Although my use of conservative is anachronistic, I think it aptly describes my interpretation of these three key republican thinkers. For each sought to conserve a particular status quo - Cicero wrote to preserve the Roman Republic and senatorial authority; Machiavelli wanted to re-establish strong republican rule in Florence and Montesquieu promoted the restoration of the nobility's authority but according to new understanding of executive and legislative power. 


\section{Classical Republicanism}

My reading of republicanism is distinct from the philosophical understanding of John Pocock and Hannah Arendt and from the political understandings of Quentin Skinner and Philip Pettit. Pocock distinguishes this tradition from liberal and natural law traditions centred on negative freedom. He contends that the republic is a paradigm of virtue, which 'consisted in a partnership of ruling and being ruled with others who must be as morally autonomous as oneself' (Pocock 2003: 75; see also Arendt 1965). Whereas Skinner's neo-roman understanding of republicanism promotes the cultivation of public-spiritedness and equal political participation of all as a means of protecting freedom against governmental domination; as such he maintains the core value of virtue and the idea that the only way to stop change and instability is through participation in the public realm. Philip Pettit advances a similar argument. If individuals participate in public debate and deliberation and are able to contest legislative proposals, then they will not be dominated by the will of those in power (Pettit 1997: 35-7, 51-79; Skinner 1998: 74-5). Classical republicanism, civic humanism, traditions of neo-roman freedom and freedom as nondomination present philosophical and political articulations of this paradigm. In contrast to these understandings, I put forward a reading that takes into account the interplay between the republican theory and the hierarchical institutional structures that three key republican thinkers advance.

The ancient ideal that individuals realise their nature as political animals by participating in the public realm for the good of all has enormous influence over normative understandings of politics. Even Montesquieu refers to this ideal when discussing the ancient republic; nevertheless, he rejects this nostalgic ideal as impracticable for large modern states. Rousseau and Paine best approximate this ideal in their promotion of the radical republic in which 
individuals as equal members of the popular sovereign participate in making laws and are therefore not dependent on any will other than their own. Yet their ideas are grounded in modern notions of equal rights and the social contract, and, in this regard, they do not promote the classical republican ideal (Paine 1995: 8-10, 230-2; Rousseau 1968: I, 1-8). My purpose is neither to interpret how the radical republicanism of Rousseau and Paine may have reshaped republican thinking nor to examine the intricacies of classical republicanism. However, I do want to emphasise that Rousseau and Paine developed their ideas in opposition to earlier articulations of republicanism and natural law theories. Ironically, the Cambridge School understanding of republicanism has more in common with the radical view than that of Cicero, Machiavelli and Montesquieu; nevertheless, this School does not situate itself in the thought of Rousseau and Paine. ${ }^{2}$ Rather it considers Machiavelli as a central thinker and includes Cicero and Montesquieu.

I contend that Cicero, Machiavelli and Montesquieu advocate a conservative style of republicanism. My understanding challenges the Cambridge School reading of Roman and early modern republicanism. Some scholars also question the Cambridge School interpretation of republicanism on similar grounds. For instance, Robert Goodin observes that 'ancient and early modern republics were layered, hierarchical status orders' (Goodin 2003: 62). Graham Maddox also describes republicanism as 'inherently conservative and elitist' (Maddox 2002: 430).

\section{Three Contexts}

Cicero, Machiavelli and Montesquieu each wrote during times of turmoil and change. Rome was on the brink of civil war. Renaissance Florence shifted from republic to autocracy and the French monarchy became increasingly absolutist in the context of the collapse of feudalism, the rise of the 
market economy and aristocratic and popular upheaval (Keohane 1980: 213-37). External change and circumstance affected internal stability. The Roman Republic had already expanded into a great empire and world power; Florence's shifting governments were assisted by external powers including the Papacy. Moreover, Renaissance discoveries of America and passage around Africa radically changed perceptions of the world (Montesquieu 1989: XXI-21). This marked the beginning of the European battle and pursuit for global domination. At the beginning of the eighteenth century France suffered defeat during the Spanish Wars of Succession and had to reassess its commercial and territorial interests abroad (Rahe 2005). At the same time commerce and international trade brought great wealth fuelling the market economy in which mobile property began to play a significant role (Montesquieu 1989: XXII-8; Sonenscher 2002). In each period contact, trade and conflict with other countries resulted in internal change and turmoil.

In response to these changes each theorist advocated an internally coherent and externally dominant republic. Each thinker wrote when states were expanding and the people were acquiring greater wealth through trade and demanding a political voice. In response to expansion and popular uprisings, power had a tendency to become more autocratic. At these major historical junctures these thinkers conceived a republic that would be able to deal with changing circumstances. None recommended reverting to a self-contained egalitarian classical republic. Rather these three republican thinkers constructed a constitution that could deal with change. They reasserted the social hierarchy in a manner that satisfied competing interests and established a centralised political leadership that could both manage social conflict and defend the republic through a policy of expansion. Thus, the republic could maintain its empire, enjoy the material benefits acquired through trade and expansion and remain stable and free. Cicero defended the Roman Republic and its empire. Machiavelli argued that unless a state is so well fortified or isolated that no one would 
consider invading it, states must expand or lie prey to external aggression. Montesquieu composed his work over a twenty-year period (1724-1748) when France and Britain struggled with each other to assert domination over maritime trade routes and colonial possessions. He advocated a republican constitution structured on the division of powers with a strong policy for the development of commerce and colonialism. None of these thinkers endorsed docile republics; rather, they promoted robust, expansive republics that could withstand change and fortune.

\section{Conservative Ideology}

Michael Oakeshott's metaphor of keeping the ship of state afloat (Oakeshott 1991: 60; 2006:

193-251) $)^{3}$ echoes Cicero's claim that '[p]eace and tranquillity are like a ship' (Cicero 1999a: I63; see also Cicero 1991). To Cicero, the ship needs a strong captain to maintain its course especially in rough seas. Oakeshott drew the metaphor to describe the pragmatism of conservative ideology. The central idea of conservatism is the desire to maintain stability when confronted with change. In the political realm, stability entails preserving the social hierarchy and respecting political authority, laws and customs (Freeden 1996: 329-31; Honderich 1990; Welsh 2003: 168). Conservatism is not entirely averse to change. It accepts gradual change (Freeden 1996: 344-5; Welsh 2003: 173-4). Its sceptical view of change strengthens the need to preserve stability and harmony and to adopt a prudential and pragmatic approach to the activity of politics (Welsh 2003: 169-75).

Conservatism considers human beings as imperfect or flawed. Therefore laws, customs and order are needed to shape behaviour. In this theory, political society is not founded upon a social contract; rather society is formed naturally. It is organic, hierarchically structured and held together by bonds of obligation and duty (Welsh 2003: 169-75). Accordingly, this structure 
promotes harmony since individuals find security in knowing their place in society (Heywood 1998: 69-79). Authority derives from the natural ranking of the social classes. In general, the propertied classes 'have a "stake" in society' and a fixed 'interest in maintaining law and order' (Heywood 1998: 80). They also possess knowledge and experience, which contributes to their ability to rule; they exercise authority naturally. Thus the protection of private property is a central conservative value that promotes security, respect for authority, law and the social order. Again I characterise as conservative the republicanism of three key thinkers who advocate mixed government. This does not mean that conservative does not apply to other types of monarchical or autocratic regimes, but rather I am using conservative as an analytical tool to highlight that this mixed republican constitution reiterates the social hierarchy within political institutions and co-opts the people to maintain a balance and stability.

Cicero, Machiavelli and Montesquieu conceptualise that society is naturally comprised of two social classes - the haves and have-nots. Cicero and Montesquieu put forward arguments to preserve the landed nobility's authority. They contend that a hierarchical and harmonious order would preserve stability within. Machiavelli, however, is more sceptical of the upper classes' claims to dominate. He is especially critical of those who owned vast landed estates and have titles. He does not write with a view to legitimating the privileges of these classes; rather he promotes glory and grandeur and accepts that there are two predominant social classes or humours that clash. The nobles desire to dominate and the people do not want to be oppressed (Machiavelli 1988b: IX, 34; Parel 1992: 1-10, 152). Machiavelli argues that these interests can be balanced and redirected to aggrandisement. In this manner the republic is free internally because class interests are satisfied and it is independent because it can defend itself against external aggression (Machiavelli 1983: I-6). 
Change arises from external factors. Expansion brought mobile wealth and changing societal, economic and political circumstances. Wealth created confidence, greater demands and determination resulting in popular unrest and strife. The powers that be responded by becoming more absolute. Therefore, the republic had to adapt in order to stay afloat or collapse into either anarchy or tyranny.

\section{Classical, Neo-roman and Democratic Republicanism}

In The Machiavellian Moment Pocock depicts the re-emergence of classical republican theory as a response to change, which is symbolised as time, contingency and fortune. The republic

had a beginning and would consequently have an end; and this rendered crucial both the problem of showing how it had come into being and might maintain its existence, and that of reconciling its end of realizing universal values with the instability and circumstantial disorder of its temporal life. Consequently, a vital component of republican theory ... consisted of ideas about time, about the occurrence of contingent events ... and about the intelligibility of the sequences ... of particular happenings that made up what we should call history (Pocock 2003: 1-2).

Change is irrational and inevitable. To maintain stability, Pocock argues, the republic had to assert virtue over fortune. 'The republic could persist only if all its citizens were so far autonomous that they could be equally and immediately participant in the pursuit of the universal good.' He elaborates. 'Only as a partnership in virtue among all citizens could the republic persist; if virtue were less than universal, its failure at one point must in time corrode its 
existence at all others' (Pocock 1989: 87). Pocock contends that the republican insistence on the universality of virtue is a result of its response to change. To control change virtue must dominate fortune, corruption and commerce. Therefore, only by asserting a universal idea of virtue can the republic maintain stability. Through political participation and the cultivation of virtue citizens could control change. Yet Pocock's interpretation is imbued with the abstract and ethical view that individuals reach the highest human ends as political animals through this activity. Anything short of this is corrupt (Pocock 1985: 42-3). It is, therefore, difficult to apply Pocock's classical republican paradigm to real situations in which individuals are not equal and do not have the same capacity to rule.

Pocock reads this virtue-based paradigm in the ideas of Machiavelli and Montesquieu. Yet, these thinkers adopt a pragmatic approach to a concrete understanding of change. They do not assert virtue as a means of attaining man's highest ends. Although Machiavelli asserts that a prince ought to use virtue to dominate fortune to maintain his state, he refers to the harsh reality of using coercive force and the threat of force for the sake of stability against internal and external threats. In contrast to Pocock's idealistic view, Cicero, Machiavelli and Montesquieu claim that the public good entails stability, hierarchy, expansion and the preservation of material goods. To them, the cultivation of virtue is the affirmation of these sorts of ends.

As with Pocock, Skinner (1978: 113-38; 2002b: 147) highlights the confrontation between virtue and fortune as a central theme in Machiavelli's thought. This confrontation is presented in terms of military virtù and the taming of fortune, as opposed to moral virtue, which staves off corruption. Despite recognising Machiavelli's innovations, Skinner nevertheless situates him in the intellectual context of Italian Renaissance civic humanism. Skinner claims that Machiavelli reaffirms the central notions of this tradition. The Discourses 'look back to the 
ideology of the communes ... thereby offering a brilliant restatement of a number of age-old questions about the values of elective and self-governing systems of rule' (Skinner 2002b: 149$50)$.

At the same time, Skinner claims that: 'For all the closeness of these links between the Discorsi and earlier traditions of republicanism ... there can be no doubt that one of Machiavelli's principal aims is to question and subvert these inherited patterns of thought' (Skinner 2002b: 154). According to Skinner, Machiavelli accepts that 'virtù names those attributes that enable citizens to help uphold the liberty and greatness of their native community', but 'he flatly repudiates the further assumption that the most important aspect of civic virtù is justice, the virtue that consists in avoiding both cruelty and the ignominy that attends the breaking of faith' (ibid.). As Skinner understands The Prince, if the security and freedom of the community are at stake, then virtù requires that one disregard the morality of an action.

In my view, virtù, in The Prince, is not a collective value but, rather, a guideline for conduct of the prince who wishes to found a 'state'. Virtù refers to how a prince can master fortune and matter, to then create either a monarchy or a republic. Virtù is about leadership and the qualities that endow a man with the charisma and strength to command a following.

According to Skinner what is necessary for contributing to the common good and liberty is participation in decision-making. This point of view entrusts political rule to those who own enough property to be autonomous. As such it ensures equality amongst the rulers, but not between the rulers and ruled. Although the people may be brought into the political sphere through their capacity to elect rulers and to validate legislation, this view does not take into account that the roles are not equal and that the system is hierarchical. Rather Skinner underlines the qualities of virtue and the good of participation, playing down the fact that the structure in 
which this is done is essentially hierarchical. Skinner infers individual equality from the notion that all individuals share in virtue and the common good. However, this individual equality is an abstraction, not action made concrete in the institutional structures.

Given that human nature is no longer seen as good, but rather as self-interested, Skinner concedes that, first, Machiavelli 'places all his faith in the mixed constitution with a bicameral legislature'; and, second, if citizens are too 'evil and self-interested' to 'act with virtù and serve the common good, they will have to be forced to do so by the coercive powers of the law' (ibid. 156). However, in my view, Machiavelli's dilemma was not so much about forcing the people to pursue virtue and the common good through active participation in the political realm; rather it was more about how to incorporate the people in the political realm so as to satisfy their interests and to preserve the elite's political rule. Involvement of the people was seen as necessary both to diminish the threat of revolution and as a source of military might.

Skinner acknowledges the difference between the people and the nobles and their humours or dispositions in Machiavelli's account. He also recognises that Machiavelli's republicanism and civic humanism differ in their attitudes to social conflict and harmony. Machiavelli's

is not the Aristotelian ideal of combining the different social elements together in such a way as to produce the most harmonious mixture. On the contrary, he assumes that ... each of these groups will at all times seek to promote its own advantage unless restrained. The course of wisdom is accordingly to take account of these ineradicable hatreds and devise a constitution that will turn these private vices into public benefits. This is what 
the Romans succeeded in doing when they gave the nobles control of the senate while assigning the tribunate to the plebs (ibid. 156-7).

This is a sound interpretation of Machiavelli's Discourses, yet it is at odds with Skinner's idea that to protect their own freedom all citizens participate equally in making laws.

The fortune and corruption versus virtue paradigm that Skinner adopts reinforces the argument for political liberty, since the people are brought into the legislative process to keep watch over the nobles. The people are meant to keep the nobles from becoming corrupt. Skinner makes the point:

The maintenance of personal liberty also depends according to Machiavelli on preventing the grandi from coercing the popolo into serving their ends. But the only way to prevent this from happening is to organise the polity in such a way that every citizen is equally able to play a part in determining the actions of the body politic as a whole. This in turn means that a readiness to serve in public office, to pursue a life of public service, to perform voluntary services, constitutes a further necessary condition of maintaining one's own liberty. Only if we are prepared 'to do good for the community', to 'help forward' and 'act on behalf of' the common good, can we hope in turn to avoid a state of tyranny and personal dependence (Skinner 2002a: 211).

Here we see the liberty versus slavery paradigm being used to motivate people into playing their part. If the people do not take an active role, then political power will become arbitrary and the people will be reduced to servitude. 
Recently, John McCormick has challenged the Cambridge School reading of republicanism, in particular Skinner's understanding of Machiavelli. In his work Machiavellian Democracy, McCormick argues that Machiavelli's republicanism is more democratic due to its mechanisms for popular control of elites than the Cambridge School recognises. He criticises Skinner for ruling 'out direct popular control of politics as a solution to the problem of elite dominance within contemporary politics' because it he has merged Machiavelli with Cicero and cannot offer any 'alternative form of "public participation" to mere voting' to 'secure individual liberty and ensure elite accountability' (McCormick 2003; 2011: 11, also 8-12). In the passage above, Skinner calls for greater direct public participation of equals to keep the grandees from ruling in their own interests. To this extent, McCormick's argument is similar to Skinner's in that McCormick interprets Machiavelli as a democratic republican who wants to curb the power of the elites. McCormick advocates popular scrutiny of ruling elites through popular institutions that can validate or cancel the passage of legislation and through people's ability to bring officeholders to account if they flout the law. This implies the existence of an independent legal system and the principle of rule of law. Both claim that Machiavelli is a republican because he seeks to engage the people in the public realm and protect freedom against the domination of ruling elites. Although McCormick criticises Skinner for misunderstanding republicanism and actually promoting a hierarchical system, I think there is a common concern and basis to their arguments.

Both Skinner's and McCormick's arguments are logical and compelling, but in Rome and Florence the people were not brought into the political realm as citizens equal to the nobles. The fact that the laws ruled over all and all were equally subject to the laws does not mean that all were treated or considered equal by the laws. Machiavelli does not argue to the contrary. 
In ancient and medieval conceptions social classes or corporate guilds, not individuals, were considered participants in the political sphere. The law differentiated between different classes of citizens and it is through membership in particular social classes or guilds that citizenship, duties and rights were conferred; these were different according to social standing and the body through which one was incorporated. The state is considered as a mixed or corporate body, which includes the various social classes and guilds (Pasquino 1994: 294-5).

This is quite a different view from the modern one where the political entity is a single body comprised of equal individuals whose citizenship, rights, liberties and duties are derived through the state. Whereas in the earlier Renaissance conception individuals enter a contract or association with a group that is a part of the political whole and it is the group or social class that relates to the body politic - the individual's relationship to the whole is mediated by the social class (Pasquino 1994: 294-5).

Ancient and Renaissance republicanism institutionalised the social hierarchy. The people were brought into the political realm because they posed a threat to the political authority and rule of the nobles. The theory of anacyclosis, metaphors of fortune, and the experience of popular uprisings demonstrated this threat. The nobles' practicing prudence and virtue allowed the people to be part of the political system in such a way that the people supported and were obedient to the nobles' authority.

\section{Conservative Roots}

I ground my understanding of the conservative roots of republicanism on the Ciceronian notion of justice as the equitable participation of the social classes in the public arena. Equitable does not mean equality, but rather refers to getting one's fair due. To Cicero, equity means that each 
citizen participates according to his class or rank. His principle of equity substantiates an inegalitarian understanding of both justice and virtue. He rejects a state of universal equality amongst all citizens because he considers it unfair to treat people of higher and lower rank the same.

For legal equality - the object of free peoples - cannot be preserved. ... And what people call equality is in fact very unfair. When the same degree of honor is given to the best and the worst (and such must exist in any population), then equity itself is highly inequitable. But that is something that cannot happen in states that are ruled by the best citizens (Cicero 1999a: I-53).

Cicero evaluates the characteristics of each social class as rational and irrational. $\mathrm{He}$ associates the best, the optimates, with the noble social classes and the worst with the popular social classes. He contends that the optimates should rule and that these men who are the best and virtuous are not equal to the rest of society. In his view, the unbridled masses should be brought under the control of the nobility seated in the senate. Cicero views the popular social classes as irrational, passionate, volatile and incapable of ruling. Only under authority of the senate are the people tempered and malleable and considered a legitimate part of the republic. Otherwise they are the masses, the multitude, the crowd and mob. Nevertheless, given the threat of popular uprising, he concedes it is necessary to allow the lower classes some political participation. Cicero accords the people the right to elect leaders. These leaders of the people could veto legislative proposals or passively endorse these. 
Neither Machiavelli nor Montesquieu think the people worthy of ruling. Machiavelli claims that a 'crowd is useless without a head'. In fact, he observes that 'a small section of the populace desire to be free in order to obtain authority over others, but the vast bulk of those who demand freedom, desire but to live in security' (Machiavelli 1983: I-44, I-16). Montesquieu reiterates the view that the people cannot be trusted to wield power; they will not 'know how to conduct the public business' (Montesquieu 1989: II-2).

The political classes shared in ruling and being ruled on an equitable basis commensurate with rank and order. The system was fair because each received his due. Peace and stability were achieved through the hierarchical structure in which each class had a role to play. Individuals endorsed the hierarchical structure by participating in the political sphere through their social class.

Some social mobility meant that individuals could rise through the ranks by advancing the ends of the republic (Cicero 1999a: I-67; Machiavelli 1989: 115). Indeed, the cultivation of virtue provided the means by which a few might rise through the ranks without undermining traditional and hierarchical structures (Najemy 2000: 87, 92). Although all members had an equal share in virtue because they desired the good of all, this did not mean that they equally shared in determining the policies and laws that support the common good. Desiring and obeying the common good are substantially different activities from making political decisions to advance it.

The protection and defence of private property are principal ends of the republic. Allotment of duties and rank varies according to the type of property possessed. Ownership of landed and fixed property and being the head of a household gave the individual the ethos and practical experience of managing and ruling over an estate. The citizen's interest in formulating 
legislation was tied to his ownership in landed property since the laws held jurisdiction over it. Virtue was attached to the fixity of property, and estate-owners were deemed to have the true interests of the whole at heart.

Mobile property also contributed to the general level of wealth in the republic, but, as it was not fixed, such property was not considered stable. Men who owned mobile property were entitled to participate only partially in politics, since their private interests were vulnerable to the sway of fortune and could be sources of corruption. ${ }^{4}$ The ranks of the people who owned sufficient mobile property were allowed to participate in the political realm, even though they remained subordinate to the landed nobility (Montesquieu 1989: XX-18; Pocock 2003: 390-1, 439-41, 484-98).

The threat of external aggression provides grounds for the republic to expand. Once a state expands, it introduces the dynamic force of change. Expansion and trade produce wealth and new forms of property. The owners of mobile property begin to contribute to the social and economic development of society. Hence, the upwardly mobile ranks of the people acquired some positive rights to participate partially in the political realm and gained the freedom to pursue their interests in security and without fear of oppression.

Cicero and Machiavelli draw upon the theory of the cycle of constitutions in support of the mixed constitution as a stable form of political rule. The classical theory asserts that there are three types of constitutions based on the rule of one, a few or many. Political rule can be either good and in the interests of the whole of society or bad and in the interests of the rulers. The three good constitutions are monarchy, aristocracy and democracy and the three bad types are tyranny, oligarchy and mob rule. Each simple constitution is inherently unstable since each good type declines into its bad form to be overthrown by another type. This cycle is never ending. 
However there is a fourth mixed constitutional type that includes elements from the three good types; it is stable because it stops the cycle of change (Balot 2010). Cicero deploys the theory to show the instability mainly of monarchy and democracy and to promote the mixed constitution of the Roman Republic in which the Senate was supreme. In his view, the main threats to stability are one man's usurpation of power and the popular desire for revolution (Cicero 1999a: I-41-55).

Machiavelli also asserts that frequent constitutional change and disarray make states prey to other powers (Machiavelli 1983: I-2). Hence in his discussion of contemporaneous constitutions, Machiavelli develops a typology of legitimate types - monarchies and republics. He argues that the simple types are unstable since power is located in a single site and will inevitably become corrupt (Machiavelli 1983: I-2). He advances an understanding of civil principality in which the rule of one man is built on the support of either the nobles or the people. Like the republic, monarchy is a legitimate type of government because it maintains rule according to laws and locates political power and authority in different sites (Machiavelli 1998b XIX). In his typology, Machiavelli (1998b IX) includes licenzia, which is either the corrupt rule of one man (tyranny) or the licence of many men (anarchy). These are the opposites of the republic. Neither despots nor the many rule according to laws established in the general interest; rather they rule according to particular whims or desires.

To Machiavelli, a well-ordered and regulated monarchy is not the arbitrary rule of one man. That is tyranny. Machiavelli draws the contrast between power regulated by laws and power that is arbitrary: 'just as princely forms of government have endured for a very long time, so, too, have republican forms of government; and that in both cases it has been essential for them to be regulated by laws. For a prince who does what he likes is a lunatic, and a populace 
which does what it likes is unwise' (Machiavelli 1983: I-58, my italics). An unruly populace can be manipulated both by a moderate leader and a demagogue. Indeed tyranny can arise out of anarchy.

Montesquieu adapts Machiavelli's typology. He argues that there are three types of constitutions - monarchical, republican (democratic and aristocratic) and despotic. Montesquieu understands monarchy as a mixed and moderate type of government in which power is channelled through the nobility (1989: II-4). The nobility limits the power of the monarch and their landed interests give them reason to defend the state and to maintain its laws. He also considers any simple constitution as despotic since it locates all power in a single body without any counterweights (Montesquieu 1989: II-5).

Montesquieu draws on the state of nature scenario to describe the linear progress from man's solitary to collective existence. In his version of the state of nature scenario, men initially live in solitude; curiosity and mutual attraction bring them to live together and form the first societies, which, eventually, erupt into war. On laying down their arms, men establish political society according to laws and political right. Montesquieu does not advocate a social contract but contends that the union of the wills of individuals establishes the civil state (Courtney 2001: 516; Montesquieu 1989: I-2-3). Although this scenario is hypothetical it reflects the categorisation of communities of his day. For instance, tribal societies were considered primitive and belonged to the state of nature. Most European states were advanced political societies (monarchies or republics), and Oriental and Asian civilisations were in decline and were subject to the despotic prince. Montesquieu's view of the world order was hierarchical. It comprised barbaric, tribal, civilised and corrupt states (Bowden 2009; Montesquieu 1989: XV-XX1). All of these were in flux. Even moderate monarchies (the Kingdom of France) and republics (Rome) were subject to 
decline. Montesquieu wanted to find a formula that keeps power from becoming absolute and corrupt and that stops the decline of constitutions.

\section{Cicero}

Cicero's political writings convey a desire to conserve the Roman Republic in which the authority of the Senate reigned supreme. The consuls acted according to the Senate's advice and the tribunes of the people strengthened senatorial authority for they acted as leaders who persuaded the people of the wisdom of the Senate's decisions. To counter threats of absolutism and populism, Cicero promotes the Roman Republic as a good and stable constitution. ${ }^{5}$ In The Republic, Cicero juxtaposes res publica with res populi. In translation, res publica res populi means that the republic is the concern or the property of the people (Cicero 1928: 65; 1999a: I39a). This famous statement has been taken to affirm the democratic values of popular legitimation and accountability (Asmis 2004; Schofield 1999). However, Cicero is ambiguous as to whether he refers to the people as the whole of society or a part of society. He uses rhetoric to let the popular social order believe that their role in politics is more effective than it actually is. At the same time, he asserts that if the people are satisfied and have their freedom, they will follow the authority of the optimates (Cicero 1999a: I-52; 1999b: III-38).

Cicero associates the people with the republic:

a people is not any group of men assembled in anyway, but an assemblage of some size associated with one another through agreement on law and community of interest. The first cause of its assembly is not so much weakness as a kind of natural herding together 
of men: this species is not isolated or prone to wandering alone, but it is so created that not even in an abundance of everything $<$ do men wish to live a solitary existence $>{ }^{6}$

The formation of society is a natural and a rational act. Men associate out of interest and through an agreement on laws. Cicero's elaboration of this definition emphasises the importance of shared public property. He indicates that individuals create civil society for the protection of private and public property. 'For political communities and citizenships were constituted especially so that men could hold on to what was theirs. It may be true that nature first guided men to gather in groups; but it was in the hope of safeguarding their possessions that they sought protection in cities' (Cicero 1991: II-73). He further discerns that every organised people, city and republic must be ruled by a deliberative function (Cicero 1999a: I-41-42). Thus he distinguishes between the association of the people in the city and the ruling body; the people and the rulers are distinct bodies and Cicero claims that the nobility ought to rule and the people ought to acquiesce in their rule.

As we have seen above, Cicero's view of private property serves to maintain the social hierarchy. He considers that the division of social classes arises from nature and that each man's place in the social hierarchy is natural. Although all share in right reason (knowledge of the natural law), reason is more developed in some than others. Some are born into superior circumstances, acquire an education and develop their faculty of reason (Cicero 1999b: I-17-28). Again, Cicero puts forward the view that the social hierarchy provides stability since each man knows where he stands and what his duty is. 'There is no reason for revolution when each person is firmly set in his own rank, without the possibility of sudden collapse' (Cicero 1999a: I-69). Cicero organises political institutions to allow the best men to predominate and concedes a 
minimal role for the people. This would create a 'combined and moderately blended commonwealth'. Cicero calls this structure concordia ordinum. He compares the 'harmony of the orders' to the harmony of an orchestra:

the state, through the reasoned balance of the highest and the lowest and the intervening orders, is harmonious in the concord of very different people. What musicians call harmony with regard to song is concord in the state, the tightest and the best bond of safety in every republic; and that concord can never exist without justice (Cicero 1999a: II-69).

Concordia ordinum is a natural and organic ordering of the social classes (Coleman 2000: 26873). It creates balance and stability since all know their rank and what is expected of them. At the same time, it is a theoretical construct that situates power and political authority in the upper classes and subordinates the lower classes. The tribunes could veto senatorial proposals; yet the popular leadership was meant to direct the people to acknowledge the wisdom of the senate and to acquiesce in its authority. Although the 'agreement on law and community of interest' differentiates between classes of citizens, the political organisation of the republic harmonises the social orders.

In concrete terms, Cicero promises the satisfaction of the interests of each social order: 'if there is not an equitable balance in the state of rights and duties and responsibilities, so that there is enough power in the hands of the magistrates and enough authority in the judgement of the aristocrats and enough freedom in the people, then the condition of the commonwealth cannot be preserved unchanged' (Cicero 1999a: II-57). The Roman republican constitution, in both practice 
and Cicero's theory, achieves this balance. The consuls exercise political power in accordance with the senatorial decrees. If the tribunes do not oppose these proposals, it is assumed that the people ratify the senate's will.

Cicero defends Servius Tullius' system of weighted voting, in which 'the votes were in the control of the wealthy rather than the majority. He made certain (something that must always be secure in a commonwealth) that the greatest number did not have the greatest power' (Cicero 1999a: II-39). Even the very poor (the proletarii) who could offer little more than their offspring were not excluded from voting. However, their voice was as insignificant as the wealth they contributed to the whole. In this manner, Cicero observes, 'no one was kept from the right to vote, but the people who had the most power in the voting were those who had the greatest interest in maintaining the state in the best possible condition' (Cicero 1999a: II-40). Those who had the greatest interest and the greatest proportion of votes were those who owned landed property. All the same, the republic is a free state for the people share in it, even if they do not have any real, substantial authority (Nicolet 1980: 57).

Cicero's republicanism sets stability and the protection of private property as its ends; to achieve these, appeals to tradition (custom), concordia ordinum and right reason support a hierarchical political order in which the two social classes participate on an unequal basis and a central power directs the whole both with regard to internal strife and external domination. $\mathrm{He}$ neither asserts that all citizens are equal nor that individuals are free from domination because they equally participate in ruling and being ruled. Rather the Roman understanding of freedom is that of security. Most people want to live in the security from arbitrary punishment and rule. The people acquired tribunes to protect their freedom and to exercise the individual right of appeal 
against arbitrary punishment (provocatio) (Brunt 1988: 281-350, 297; Lintott 1999: 35-9;

Wirszubski 1968: 24-5).

\section{Machiavelli}

Over Machiavelli's lifetime, Florence changed regimes four times. When the Soderini administration was overturned by the Medician oligarchy, Machiavelli was arrested and tortured. On his release, his post in the Soderini government was no longer. He then began writing about politics (de Grazia 1989: 1-34; Ridolfi 1963). He composed his works a few decades after the discoveries of the shipping passage around Africa and the new world. His world was fastchanging; great powers developed alliances and manipulated political rule in smaller Italian states and began to lay dominion over newly discovered lands. Machiavelli sought to create a stable and strong republican regime to Florence that would both enable Florence to become a regional power to stand up to the great powers of his day (France, Spain and the Papacy) that manipulated the small Italian city-republics (Machiavelli 1988a; 1988b: XXVI; 1989). Hence Machiavelli recommends an expansive republic constructed on the example of the great Roman Republic.

Machiavelli's corpus is considered enigmatic. The Prince and The Discourses are considered contrary works, with republicanism frequently defined in opposition to monarchy. However, the two works are not so antithetical (Baron 1961; Gomez and Nederman 2002). Indeed, that they are both about regimes in which political society is ordered according to the social hierarchy suggests, to me, a continuity. Republics are suited to states in which differences between the nobility and the people are slim, and monarchies where there is great disparity between the nobles and the people; hence the need for an arbitrator, the prince. In both works, 
Machiavelli praises two mixed constitutional polities in history: the Kingdom of France and the Roman Republic (Machiavelli 1983: I-16; 1998b XIX). He states a preference for republics but considers constitutional monarchies in which kings rule according to laws well-ordered.

With Cicero, Machiavelli admires the Roman republic. In contrast to Cicero and his civic humanist contemporaries, Machiavelli rejects the understanding of political society as harmonious (Duff 2011). Machiavelli declares that the social discord between the nobles and the people made Rome both free and great.

I am convinced that the Roman type of constitution should be adopted, not that of any other republic .... Squabbles between the populace and senate should, therefore, be looked upon as an inconvenience which is necessary to put up with in order to arrive at the greatness of Rome (Machiavelli 1983: I-5, my italics).

Like the human body, Machiavelli observes that the political body is made up of two competing humours or interests - the nobles and the people (Parel 1992: 101-12). His conception of society is organic and natural based on a sociological understanding that society is comprised of two social classes.

Machiavelli considers that the mixed constitution deals with social conflict and operates without creating a false sense of harmony. He observes that the creation of Roman tribunes made the Republic 'more perfect' (Machiavelli 1983: I-4). Provided that the people are not oppressed and have an outlet through which to voice their concerns, then, Machiavelli claims, there is no need to fear popular uprising, or, 'to regard such tumults as harmful' (Machiavelli 1983: I-4). The condition that the people have an outlet to express their concerns is the significant point 
since it is the basis on which they are admitted into the political realm. Machiavelli praises the Roman Republic which made the people the guardians of liberty, allowed for the predominance of the nobility and granted imperium and leadership to the consuls (Machiavelli 1983: I-2-4).

Machiavelli is the most radical of the three thinkers for his positive view of social conflict could strengthen the popular voice (McCormick 2001). Here, as McCormick argues, Machiavelli places great weight on the people and it is significant that he claims they should have an outlet to express their opinions. He has great faith in the people and presents them in a better light than as fickle and irrational masses. However, by promoting social discord and recognising competing interests and humours, he maintains social division, inequality and hierarchy (Parel 1992: 152). Although he recognises the relative equality between the social classes in republics, he does not consider them equal and bearing equal weight. He worked within a conception in which there were two unequal social classes whose political rights and duties were commensurate with their rank. The people tempered the power of the grandees but did not enjoy the equality by which they might question the grandees' authority.

Despite Machiavelli's portrayal of the tribunes of the people as guardians of liberty, he claims that they were leaders who 'for the security' of the plebs 'were invested with such prerogatives and standing that henceforth they could always mediate between the plebs and the senate and curb the arrogance of the nobility' (Machiavelli 1983: I-3, my emphasis). Indeed, in Rome, the tribunes had the power to veto senatorial initiative but in general they led the people according to the opinion of the senate. Machiavelli was radical for rejecting harmony as a goal and emphasising the potential fruitfulness of social conflict. However, I do not think this necessarily amounted to populism. 
Machiavelli's understanding of politics is realist; he does not advocate normative ideals, but rather demonstrates how to maintain a republic or a principality by balancing competing classes, by limiting the upper classes and empowering the lower classes. To this extent his understanding is pragmatic. Machiavelli observes: 'Well-ordered states and wise rulers have always been very careful not to exasperate the nobles and also to satisfy the people and keep them contented; this is one of the most important things for a ruler to do' (Machiavelli 1988b: XIX). Moreover, in his constitutional designs for Florence, Machiavelli proposes a mixed government in which the social orders participate differentially according to rank. 'There is no other way of escaping these ills than to give the city institutions that can by themselves stand firm. And they will always stand firm when everybody has a hand in them, and when everybody knows what he needs to do and in whom he can trust, and no class of citizen, either through fear for itself or through ambition, will desire revolution' (Machiavelli 1989: 115).

In The Discourses Machiavelli is clear that the Roman expulsion of the kings was an expulsion of the title and that royal power continued to exist amongst other constitutional powers. 'So when it came to pass that the kings lost their sovereignty ... those who had expelled them at once appointed two consuls to take the place of the king so that what they expelled was the title of the king, not the royal power' (Machiavelli 1983: I-2, my italics). Machiavelli then claims that the people were enemies to the name of king, not to the royal power itself. 'If we consider the Roman populace it will be found that for four hundred years they were enemies to the very name of king and lovers of glory and of the common good of their country' (Machiavelli 1983: I-58). The royal office and power of a king were embodied in an elected executive of the republic. This power was subject to laws and constitutional mechanisms (the veto) that regulated election and duration of office. Therefore, princely power is part of 
republican institutions. Machiavelli emphasises the monarchical element in the mixed constitution and demonstrates that it is important to have a strong leadership in the republic that arbitrates social conflict and directs military aggrandisement.

To Machiavelli, popular demands did not amount to usurping political authority and power. Rather the people wanted to secure freedom from the noble's oppression and if that negative freedom were secured then the people would not rise against the state.

He [the prince] will find that a small section of the populace desire to be free in order to obtain authority over others, but that the vast bulk of those who demand freedom, desire but to live in security. For in all states whatever be their form of government, the real rulers do not amount to more than forty or fifty citizens .... As for the rest, who demand but to live in security, they can easily be satisfied by introducing such institutions and laws as shall, in conjunction with the power of the prince, make for the security of the public as a whole (Machiavelli 1983: I-16).

Ultimately competing social interests need not be harmonised. To Machiavelli, conflict is necessary, inevitable and natural. This idea is not a populist one in that his recognition of conflict does not go so far as to include the popular right to rule (Machiavelli 1988b: IX, XV). Even though he trusts the people's judgement, he does not claim that they ought to rule. The people's claim for greater authority is satisfied by granting them liberty, amounting to minimal participation but effective security. As noted above, Skinner claims that in order to secure negative liberty, the people must participate in making the laws (Skinner 1998: 74-5). But 
Machiavelli's argument, echoing Cicero, claims that if the people are free, they will not want to rule or take part in decision-making.

At the same time, Machiavelli asserts that differing class interests support the preservation of the ruling elite's authority and contribute to the expansion and glory of the regime as a whole. Machiavelli argues:

Should, then, anyone be about to set up a republic, he should first inquire whether it is to expand, as Rome did, both in dominion and in power, or is to be confined to narrow limits. In the first case it is essential to constitute it as Rome was constituted and to expect commotions and disputes of all kinds which must be dealt with as best they can, because without a large population, and this well armed, such a republic will never be able to grow, or to hold its own should it grow. In the second case it might be constituted as Sparta and Venice were, but, since expansion is poison to republics of this type, it should use every endeavour to prevent it from expanding, for expansion, when based on a weak republic, simply means ruin (Machiavelli 1983: I-5).

Small, isolated republics constituted on equality cannot cope with change; either they collapse or are invaded. Machiavelli connects the internal constitution of the republic with its external desires and ends, which is to say expansion and growth. For if a state does not expand it lays prey to other powers. Furthermore, he advocates establishing a citizen militia that would defend the republic and allow it to expand. A citizen army would contribute to stability by countering individual princes who, in his day, raised mercenary armies. 
Machiavelli argues for a princely power that is subject to the limits of office and to the laws. This limited princely power in the person of a single man contrasts with the Roman institution of the two consuls. Ultimately, competition between these consuls brought Rome down. Hence a centralised princely power contributes to stability. This structure influenced Montesquieu's argument against an imperialist and absolute regime in favour of a constitutional republic.

\section{Montesquieu}

In The Spirit of the Laws, Montesquieu seeks to conserve the ancient authority and privileges of the nobility that had slowly been eroded by the monarchical and religious powers that ruled France in his day. He argues to preserve the grandeur of France as a great and expansive power but also he draws on the story of Gothic government in which the key orders of society participated and created a stable and temperate government (Montesquieu 1989: XI-8). Montesquieu advocates the conservation of moderate political rule based on the authority of the landed nobility and supported by the power of the monarch and the people. He reconceptualises the political sphere as one of power. He argues that to secure freedom and avoid despotism power must be divided into its executive and legislative counterparts. He develops his constitutional theory about dividing and limiting sovereignty in opposition to Bodin's and Hobbes' doctrines of absolute and unlimited sovereignty. Montesquieu's mechanistic approach of cause and effect informs his analysis. At the same time, his historical understanding of moderate government in the Roman Republic and the French monarchy supports his doctrine. Much of The Spirit of the Laws is devoted to the examination of the history of the French monarchy and of ancient republics. This historical and sociological knowledge legitimates his 
arguments for restoring the nobility's political authority (la thèse nobiliaire) and counterarguments in favour of maintaining the monarchy (la thèse royale).

Montesquieu reproduces the social hierarchy in the bicameral legislature. The landed nobility sit in the upper chamber and the people's representatives occupy the lower chamber. In a similar vein to Cicero, he justifies equity.

In a state there are always some people who are distinguished by birth, wealth, or honors; but if they were mixed among the people and if they had only one voice like the others, the common liberty would be their enslavement and they would have no interest in defending it, because most of the resolutions would be against them. Therefore, the part they have in legislation should be in proportion to the other advantages they have in the state, which will happen if they form a body that has the right to check the enterprises of the people, as the people have the right to check theirs (Montesquieu 1989: XI-6).

Montesquieu distinguishes two other functions of power: la faculté de statuer and la faculté d'empêcher. The first refers to the power to make laws and the second is the ability to stop or to veto these. Montesquieu recommends that each chamber have their own assemblies and deliberations apart. He also limits the nobility's legislative authority in instances where it 'could be induced to follow its particular interests and forget those of the people' as in the making of taxation laws. Here the nobility should 'take part in legislation only through its faculty of vetoing'. Both chambers can veto each other and the executive power can veto the legislature, but the legislative power cannot veto the executive (Montesquieu 1989: XI-6). 
Montesquieu promotes popular representation in the lower chamber since he thinks the people too numerous to make the laws.

As, in a free state, every man, considered to have a free soul, should be governed by himself, the people as a body should have legislative power; but, as this is impossible in large states and is subject to many drawbacks in small ones, the people must have their representatives do all that they themselves cannot do (Montesquieu 1989: XI-6).

Although Montesquieu refers to individual equality, he still understands society as an organic whole in which there is social stratification. He does not think the people are apt to rule. He argues that they should participate in government only 'to choose their representatives'; for 'this is quite within their reach'. The representatives are not allowed 'to make some resolution for action, a thing it would not do well'. But they can 'make laws' by passing the nobility's proposals and 'see if those they have made have been well executed' (Montesquieu 1989: XI-6). Montesquieu divides executive power into the power to execute and the power to judge. These are distributed to one man and an independent judiciary respectively (Montesquieu 1989: XI-6). He recommends a monarch to act as the executive power, which enjoys an unreciprocated veto over the legislative power, conducts foreign affairs, commands the army and maintains internal and external security (de Dijn 2011). The executive's veto over the legislature is meant to prevent the legislature from becoming 'tyrannical' (Montesquieu 1989: XI-6).

Montesquieu calls this political structure the 'fundamental constitution'. 'Here, therefore is the fundamental constitution of the government of which we are speaking. As its legislative body is composed of two parts, the one will be chained to the other by their reciprocal faculty of 
vetoing. The two will be bound by the executive power, which will itself be bound by the legislative power' (Montesquieu 1989: XI-6). His argument that the constitution can move forward only when all powers act together, promotes harmony. 'The form of these three powers should be rest or inaction. But as they are constrained to move by the necessary motion of things, they will be forced to move in concert' (Montesquieu 1989: XI-6). Although he depicts the English constitution as one that best promotes freedom, the language he uses to do so is prescriptive, formulated in the conditional and subjunctive moods as opposed to the descriptive language he employs in examining republics, monarchies and despotisms. Thus I take his admiration of England and of its constitution as normative (Montesquieu 1989: XIX-27; Rahe 2005.

As with Machiavelli, Montesquieu associates the republican elements of the few and the many with the monarchical element of the one. Montesquieu is clear that republics and monarchies can combine to produce a very strong and expansionary constitution.

If a republic is small, it is destroyed by a foreign force; if it is large, it is destroyed by internal vice. $[\ldots]$

Thus it is very likely that ultimately men would have been obliged to live forever under the government of one alone if they had not devised a kind of constitution that has all the internal advantages of a republican government and the external force of monarchy (Montesquieu 1989: IX-1).

Although this passage is about a 'federal republic', Montesquieu describes it as a powerful constitution that establishes the authority of the few and the freedom of the many and integrates 
the external force of monarchy, whose 'spirit is war and expansion' (Montesquieu 1989: IX-2). Moreover his 'fundamental constitution' does precisely this - it combines the executive power of one with the legislative power of the few and the many. He declares that ' $[\mathrm{t}]$ his sort of republic, able to resist external force, can be maintained at its size without internal corruption: the form of this society curbs every drawback' (Montesquieu 1989: IX-1).

This passage is situated in Book IX of The Spirit of the Laws that treats defensive force. The following book, on offensive force, focuses on the rights of war and conquest. Montesquieu justifies war for the preservation of the state against aggression and against the threat of aggression: 'the natural right of defense sometimes carries with it a necessity to attack, when one people sees that a longer peace would put another people in a position to destroy it and that an attack at this moment is the only way to prevent such destruction' (Montesquieu 1989: X-2). On conquest, Montesquieu explains that the right to conquer derives from that of war. He further explicates that '[c]onquest is an acquisition; the spirit of acquisition carries with it the spirit of preservation and use, and not that of destruction' (Montesquieu 1989: X-3). He views the colonies of his day as objects of acquisition to be used for the exploitation of their resources. In this same chapter, Montesquieu clarifies the contemporary right of nations according to which a 'state continues to govern its conquest according to its own laws and takes for itself only the exercise of the political and civil government'. He then applauds modern reasoning, philosophy and mores for being so advanced compared to those of the Romans who exterminated the citizens of its conquests. To Montesquieu, contemporary forms of colonial conquest were good for commerce and were civilized because they did not destroy the colonies but rather used them for their resources and in exchange provided the colonies civil government and defence (Howse 2006: 639-708; Montesquieu 1989: XXI-21). 
Commerce and international trade contributed to the development of the domestic and international market economy and transformed feudal structures (Larrère 2001: 346-53). Increased internal wealth put pressure on the state to accommodate a new mercantilist social class. Commerce threatened the landed nobility's claim to political authority (Montesquieu 1989: SL, XX-22-23). The mercantilist class contributed, through taxation, to the economy and the public good. This provided the basis for citizenship and political participation. The new basis of citizenship (commerce) threatened the old basis of citizenship (virtue). As their property was mobile, the people were not seen as having a fixed interest in the state and were considered prone to corruption since they could be bought (Pocock 2003: 486-503). Consequently, their role in the state was made commensurate to standing. Nonetheless, including the people in the political realm was radical especially since, in France, the people had no political rights. At the same time, he does not promote rule of the people and he does not couch this in terms of democracy but rather recommends a constitutional balance of powers that best promotes freedom and includes a monarchical executive power, two legislative chambers comprised of hereditary nobles and popular representatives.

To Montesquieu, commerce entailed the acquisition and colonisation of overseas territories for the exploitation and trade of natural resources. He considered colonialism was necessary to protect territories and trade routes (Manicas 1981: 345-7). In a chapter entitled 'The discovery of two new worlds: the state of Europe in this regard', which is located in a book on commerce and 'the revolutions it has caused in the world', Montesquieu argues that expansion for the purposes of trade is neither despotic nor imperialistic. Rather it is 'to engage in commerce under better conditions' and 'only the mother country can trade with the colony'. To Montesquieu the aim 'was to extend commerce, not to found a new town or a new empire'. He 
recognises that 'the colonies are disadvantaged since they 'lose their liberty of commerce'. But this 'is visibly compensated by the protection of the mother country, which defends them by her arms or maintains them by her laws' (Montesquieu 1989: I-21). These statements follow the logic regarding the rights of conquest and of nation. Further in this chapter, Montesquieu describes international trade in natural and human resources between four continents.

The consequence of the discovery of America was to link Asia and Africa to Europe. America furnished Europe with the material for its commerce in that vast part of Asia called the East Indies.

Silver, that metal so useful to commerce as a sign, was also the basis for the greatest commerce of the universe as a commodity. Finally, voyages to Africa became necessary; they furnished men to work the mines and lands of America.

In conclusion, he praises Europe's power and progress which is so great that 'nothing in history is comparable to it' (Montesquieu 1989: XXI-21).

Montesquieu called his constitution a 'masterpiece of legislation' (Montesquieu 1989: V14) because it combined the power of one to command and lead with the authority of the nobility and freedom of the people. Indeed, it is a powerful constitution that creates freedom and security at home and promotes an expansive foreign policy that secures international trade and commerce.

\section{Conclusion}


The conservative roots of republicanism are grounded in the conception of justice as equity. The good of the republic is seen in terms of creating a balanced and stable constitution, which satisfies the different interests of the social classes. The republican constitution promotes the hierarchical participation of the upper and lower classes according to rank. The strength of this constitution lies in its ability to remain stable while expanding and confronting change. Cicero, Machiavelli and Montesquieu developed the core ideas of this conservative line of republican thought. Cicero conceptualised the mixed constitution as harmonising the social orders and supported the Roman Republic's empire (Schofield 2013). Machiavelli drew on Roman history to advance his view that Rome was a perfect and free republic. He contributed the idea of adopting a centralised princely power in the republican constitution rather than locating this power in two consuls. He demonstrated that a strong princely power could both mediate social conflict and facilitate the republic's expansion. Montesquieu reformulated these ideas in modern terms. He advanced the theory of the separation and balance of powers to protect individual freedom and to promote commerce. This republican history is relevant to our understanding of constitutions today. It allows us to see how constitutions evolve in contexts of change and instability and how they incorporate the various parts of society.

Manjeet Ramgotra holds a PhD in Political Philosophy from the LSE and is a senior teaching fellow in the Department of Politics and International Studies at SOAS, University of London. Her current research focuses on the history of republican ideas, empire and comparative political theory; recently she has been working on the idea of the republic in Jawaharlal Nehru's preindependence writings. Her recent publications include 'Republic and Empire in Montesquieu's 'Spirit of the Laws', (Millennium: Journal of International Studies, forthcoming).

\section{Acknowledgements}

I would like to thank the editors and anonymous reviewers for their constructive comments that have greatly improved this article. For their support and insight, I also thank John Charvet, Pasquale Pasquino, Jennifer Welsh, David Boucher, Nadia Urbinati, Georg Cavallar, Kelvin 
Knight, Jens Olesen, Julia Gallagher, Evgeny Roshchin, Antti Tahvanainen and Mary Ann Hushlak.

\section{References}

Althusser.L. Machiavelli and Us, trans. G. Elliot, ed. F. Matheron. London: Verso.

Arendt, H. 1965. On Revolution. London: Penguin Books.

Asmis, E. 2004. ‘The State as a Partnership: Cicero's Definition of Res Publica in his Work On the State', History of Political Thought XXV(4): 569-99.

Balot, R. 2010. 'Polybius' Advice to the Imperial Republic', Political Theory 38(4): 483-509.

Baron, H. 1961. 'Machiavelli: The Republican Citizen and the Author of "The Prince"', English Historical Review 76: 217-53.

Boucher, D. 2005. 'Oakeshott, Freedom and Republicanism', British Journal of Politics and International Relations 7: 81-96.

Bowden, B. 2009. Empire of Civilization: The Evolution of an Imperial Idea. Chicago: University of Chicago Press.

Brunt, P. A. 1988. 'Libertas in the Republic', in P. A. Brunt (ed.), The Fall of the Roman Republic and Related Essays. Oxford: Clarendon Press, 281-350.

Cicero, M. T. 1928. De re publica and De legibus, vol. XVI, ed. G. P. Gould, trans. C. W. Keyes. Cambridge: Harvard University Press.

Cicero, M. T. 1991. On Duties, eds M. T. Griffin and E. M. Atkins. Cambridge: Cambridge University Press.

Cicero, M. T. 1999a. On the Commonwealth, in J. Zetzel (ed.), On the Commonwealth and On the Laws. Cambridge: Cambridge University Press, 1-103. 
Cicero, M. T. 1999b. On the Laws, in J. Zetzel (ed.), On the Commonwealth and On the Laws. Cambridge: Cambridge University Press, 105-175.

Coleman, J. 2000. A History of Political Thought: From Ancient Greece to Early Christianity, vol. I. Oxford: Blackwell.

Courtney, C. P. 2001. 'Montesquieu and Natural Law', in D. W. Carrithers et al. (eds), Montesquieu's Science of Politics: Essays on The Spirit of Laws. Oxford: Rowman and Littlefield, 41-67.

de Dijn, A. 2011. 'On Political Liberty: Montesquieu's Missing Manuscript', Political Theory 39(2): 181-204.

de Grazia, S. 1989. Machiavelli in Hell. London: Harvester Wheatsheaf.

Duff, A. 2011. 'Republicanism and the Problem of Ambition: The Critique of Cicero in Machiavelli’s Discourses', Journal of Politics 73(4): 980-92.

Freeden, M. 1996. Ideologies and Political Theory: A Conceptual Approach. Oxford: Clarendon Press.

Gomez, T. V. and C. J. Nederman. 2002. 'Between Republic and Monarchy? Liberty, Security, and the Kingdom of France in Machiavelli', Midwest Studies in Philosophy XXVI: 8293.

Goodin, R. 2003. 'Folie Républicaine', Annual Review of Political Science 6: 55-76.

Heywood, A. 1998. Political Ideologies: An Introduction. London: MacMillan.

Honderich, T. 1990. Conservatism. London: Hamish Hamilton.

Hörnqvist, M. 2005. Machiavelli and Empire. Cambridge: Cambridge University Press.

Howse, R. 2006. 'Montesquieu on Commerce, Conquest, War, and Peace', Brooklyn Journal of International Law 31(3): 639-708. 
Keohane, N. 1980. Philosophy and the State in France: The Renaissance to the Enlightenment. Princeton: Princeton University Press.

Larrère, C. 2001. 'Montesquieu on Economics and Commerce', in Montesquieu's Science of Politics: Essays on The Spirit of Laws. Oxford: Rowman and Littlefield, 335-73.

Lintott, A. 1999. The Constitution of the Roman Republic. Oxford: Clarendon Press.

Machiavelli, N. 1983. Discourses on the First Ten Books of Titus Livy, ed. L. J. Walker. London: Penguin Books.

Machiavelli, N. 1988a. Florentine Histories, eds L. F. Banfield and H. C. Mansfield, Jr. Princeton: Princeton University Press.

Machiavelli, N. 1988b. The Prince, trans. R. Price, ed. Q. Skinner. Cambridge: Cambridge University Press.

Machiavelli, N. 1989. 'A Discourse on Remodelling the Government of Florence', in A. Gilbert (ed. and trans.), Machiavelli, the Chief Works and Others, vol. I. Durham: Duke University Press, $101-15$.

Maddox, G. 2002. 'The Limits of Neo-Roman Liberty', History of Political Thought XXIII(3): $418-31$.

Manicas, P. T. 1981. 'Montesquieu and the Eighteenth Century Vision of the State', History of Political Thought II(2) 313-47.

McCormick, J. P. 2001. 'Machiavellian Democracy: Controlling Elites with Ferocious Populism', APSR 95(2): 297-313.

McCormick, J. P. 2003. 'Machiavelli Against Republicanism: On the Cambridge School's “Guicciardinian Moments", Political Theory 31(5): 615-43.

McCormick, J. P. 2011. Machiavellian Democracy. Cambridge: Cambridge University Press. 
Montesquieu, C-L de Secondat. 1989. The Spirit of the Laws, eds. and transl. A. Cohler et al. Cambridge: Cambridge University Press.

Najemy, J. 2000. 'Civic Humanism and Florentine Politics', in ed. J. Hankins, Renaissance Civic Humanism: Reappraisals and Reflections. Cambridge: Cambridge University Press, 75104.

Nicolet, C. 1980. The World of the Citizen in Republican Rome, trans. P. S. Falla. Berkeley: University of California Press.

Oakeshott, M. 1991. Rationalism in Politics and Other Essays. Indianapolis: Liberty Press.

Oakeshott, M. 2006. Lectures in the History of Political Thought, eds T. Nardin and L. O’Sullivan. Exeter: Imprint Academic.

Paine, T. 1995. Rights of Man, Common Sense and Other Political Writings, ed. M. Philp. Oxford: Oxford University Press.

Parel, A. 1992. The Machiavellian Cosmos. London: Yale University Press.

Pasquino, P. 1994. 'Thomas Hobbes: La Condition Naturelle de l'Humanité', Revue française de Science Politique 2: 294-307.

Pettit, P. 1997. Republicanism: A Theory of Freedom and Government. Oxford: Clarendon Press. Pocock, J. G. A. 1985. Virtue, Commerce and History. Cambridge: Cambridge University Press. Pocock, J. G. A. 1989. Politics, Language and Time: Essays on Political Thought and History. Chicago: The University of Chicago Press.

Pocock, J. G. A. 2003. The Machiavellian Moment: Florentine Political Thought and the Atlantic Republican Tradition, 2nd edn. Princeton: Princeton University Press.

Rahe, P. 2005. 'The Book that Never Was: Montesquieu's Considerations on the Romans in Historical Context', History Political Thought XXVI(1): 43-89. 
Richardson. J. S. 1991. 'Imperium Romanum: Empire and the Language of Power', Journal of Roman Studies 81: 1-9.

Ridolfi, R. 1963. The Life of Niccolò Machiavelli, trans. C. Grayson. London: Routledge and Kegan Paul.

Rousseau, J-J. 1968. The Social Contract. ed. and transl. M. Cranston. Harmondsworth, Middlesex: Penguin Books.

Schofield, M. 1999. 'Cicero's Definition of Res Publica,' in J. G. F. Powell (ed.), Cicero the Philosopher. Oxford: Clarendon Press, 63-83.

Schofield, M. 2013. 'Cosmpolitanism, Imperialism and Justice in Cicero's Republic and Laws', Intellectual History and Political Thought 2(1): 5-34.

Skinner, Q. 1978. The Foundations of Modern Political Thought, 2 vols. Cambridge: Cambridge University Press.

Skinner, Q. 1998. Liberty before Liberalism. Cambridge: Cambridge University Press.

Skinner, Q. 2002a. 'The Ideal of Negative Liberty: Machiavellian and Modern Perspectives', in Visions of Politics: Renaissance Virtues, vol. II. Cambridge: Cambridge University Press $186-212$.

Skinner, Q. 2002b. 'Republican Virtues in an Age of Princes', in Visions of Politics: Renaissance Virtues, vol. II. Cambridge: Cambridge University Press, 118-59.

Sonenscher, M. 2002. 'Republicanism, State Finances and the Emergence of Commercial Society in Eighteenth-century France - or from Royal to Ancient Republicanism and Back', in M. van Gelderen and Q. Skinner (eds), Republicanism: A Shared European Heritage, vol. II. Cambridge: Cambridge University Press, 275-91. 
Springborg, P. 1992. Western Republicanism and the Oriental Prince. Austin: University of Texas Press.

Urbinati, N. 2012. 'Competing for Liberty: The Republican Critique of Democracy', American Political Science Review 106(3): 607-21.

Welsh, J. 2003. "II" is for Ideology: Conservatism in International Affairs', Global Society 17(2): $165-85$.

Wirszubski, C. 1968. Libertas as a Political Idea at Rome during the Late Republic and Early Principate. Cambridge: Cambridge University Press.

Wootton, D. 1994. 'Introduction: The Republican Tradition: From Commonwealth to Common Sense', in D. Wootton (ed.), Republicanism, Liberty, and Commercial Society, 16491776. Stanford: Stanford University Press, 1-41.

\footnotetext{
${ }^{1}$ It is difficult to use 'people' and 'nobility' consistently given the various contexts of each ${ }^{2}$ Pettit (1997: 19, 110-35, 252-3) claims he does not adhere to the democratic populism of Rousseau, yet he admits that his view of non-domination and contestation derive from Rousseau.

${ }^{3}$ Boucher (2005) associates Oakeshott's conservatism with Roman republicanism, 81-96.

${ }^{4}$ I refer here to the equites, bankers and merchants of Rome, Florence and France respectively whose wealth was based on moveable goods (Montesquieu 1989: XX-23).

${ }^{5}$ In On the Laws, Cicero examines and advocates the reforms Sulla made to the Roman Republican constitution. On the Laws had not been lost to posterity as On the Commonwealth had been. Yet the existence of the latter work was known through Augustine's quotation of the passage I cite below. On the Commonwealth was found in the nineteenth century.

${ }^{6}$ Cicero, Commonwealth, I-39, Zetzel's parentheses.
} 